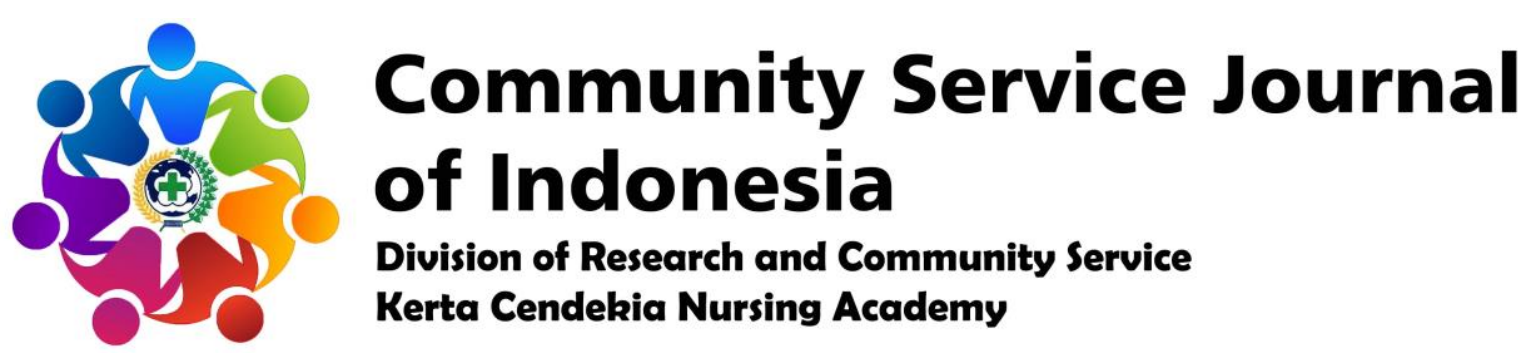

https://ejournal-kertacendekia.id/index.php/csji/index

Community Service Journal of Indonesia 2 (1) (2020): 14-17

Doi: https://doi.org/10.36720/csji.v2i1.144

\title{
IMPROVING KNOWLEDGE ABOUT CLEAN AND HEALTHY LIVING BEHAVIORS IN CHILDREN
}

\author{
Kusuma Wijaya Ridi Putra ${ }^{1}$, Sri Wahyuni Ahmad ${ }^{2}$, Leli Anggita ${ }^{2}$, Marita Milenia ${ }^{2}$, \\ Nafarotul Ilmiyah ${ }^{2}$, Apri Wijaya ${ }^{2}$, Tita Hiyasti ${ }^{2}$
}

${ }^{1}$ Lecturer of Kerta Cendekia Nursing Academy, Sidoarjo
${ }^{2}$ Students of Kerta Cendekia Nursing Academy, Sidoarjo

\begin{abstract}
Health promotion activities on clean and healthy living behavior at the Elementary School of Rangkah Kidul, Sidoarjo is one form of community service in the form of counseling aimed at increasing children's knowledge about the importance of clean and healthy living behaviors in daily activities. The activity was carried out on November 18, 2019 at the Elementary School of Rangkah Kidul, Sidoarjo. The target is the students of the Elementary School of Rangkah Kidul, Sidoarjo. Before the activity is carried out, there is a process of compiling the activity for approximately 3 weeks before the activity is carried out, starting from determining the theme of counseling to submitting permits to the parties concerned. As a form of evaluation, the activity was attended by 40 students from class III of the Elementary School of Rangkah Kidul, Sidoarjo. Participants participated in the activity with great enthusiasm, health promotion activities were able to run on time and smoothly.
\end{abstract}

Keywords: Clean and healthy lives, washing hand, health behaviors knowledge.

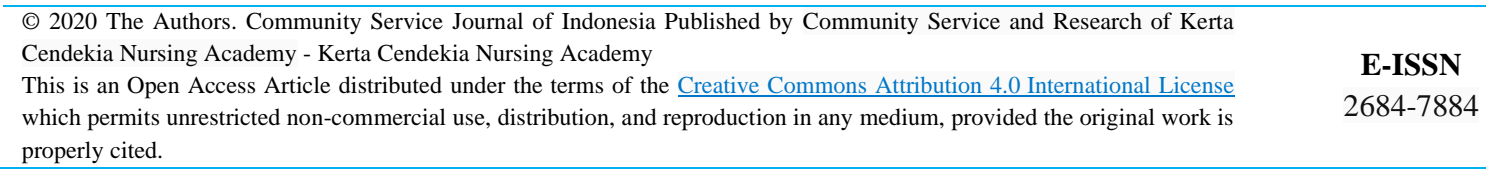

E-ISSN

2684-7884

\section{INTRODUCTION}

Clean and Healthy Life Behavior is a set of behaviors that is practiced on the basis of awareness as a result of learning that enables individuals / groups to help themselves in the health sector and play an active role in realizing public health status. PHBS at school is an effort to empower students, teachers, and the school community to know, want and be able to practice PHBS, and play an active role in creating healthy schools. According to the Indonesian Ministry of Health (1997), the purpose of PHBS is to increase knowledge, awareness, willingness, and the ability of people to live clean and healthy, as well as 
increase the active participation of the community including the business world in an effort to realize optimal health degrees. The emergence as a disease that often attacks school-age children (ages 6-10), is generally associated with PHBS. Therefore, planting the values of PHBS in schools is an absolute necessity and can be done through the School Health Business (UKS) approach.

Many diseases can be avoided by PHBS, starting from diarrhea, dengue fever, bird flu, or even swine flu which is rife lately. One factor that supports PHBS is environmental health. Two important terms in environmental health must be understood and interpreted equally by all health workers involved so that the activities carried out can be successful.

The environment is defined as the accumulation of physical, social, cultural, economic and political conditions that affect the lives of the community. While the health of a community depends on the integrity of the physical environment, human values in social relations, the availability of resources needed in sustaining life and disease prevention, dealing with health disorders naturally, work and education that can be achieved, cultural preservation and tolerance of different types, access from lineage and a sense of power and hope.

Environmental health is a very important thing in the implementation of community care. So, in order to achieve the success of community care interventions there needs to be a special discussion on environmental health PHBS.

\section{OBJECTIVES}

\section{General Purpose}

After counseling, all students of Class III of the Elementary School of Rangkah
Kidul, Sidoarjo are expected to be able to increase knowledge about clean and healthy living behavior.

\section{Special Purpose}

After counseling, all representatives of students of Class III of the Elementary School of Rangkah Kidul, Sidoarjo are expected to be able to:

1. Understand about clean and healthy life behavior.

2. Explain the kinds of clean and healthy living behaviors.

3. Know and applying those who have to carry out clean and healthy behaviors in school.

4. Know and practice how to wash hands properly.

5. Mention the impact of not doing clean and healthy life behaviors.

\section{PLAN OF ACTION}

\section{Strategy Plan}

The strategy plan implemented, including:

1. Coordinate with the principal of the Elementary School of Rangkah Kidul, Sidoarjo to request permission to carry out health education as a nursing program and to help provide useful knowledge for students of the Elementary School of Rangkah Kidul, Sidoarjo.

2. Establish a time contract with students of the Elementary School of Rangkah Kidul, Sidoarjo.

3. Providing health education about clean and healthy life behaviors in the Elementary School of Rangkah Kidul, Sidoarjo. 


\section{Implementation}

Actions taken in the implementation of these activities, including:

1. Contacting the principal of the Elementary School of Rangkah Kidul, Sidoarjo to ask permission to carry out these activities and gather the students of the Elementary School of Rangkah Kidul, Sidoarjo.

2. Prepared the place and media for health promotion.

3. Carried out of the material about clean and healthy life behaviors to the all representatives of students of Class III of the Elementary School of Rangkah Kidul, Sidoarjo.

\section{Setting}

This activity was carried out at the Elementary School of Rangkah Kidul, Sidoarjo on November 18, 2019.

\section{Target}

Target in this activity is all of the students of Class III of the Elementary School of Rangkah Kidul, Sidoarjo.

\section{RESULTS AND DISCUSSION}

The activity starts at 12.00 until 12.45 WIB. The activity was carried out at the Elementary School of Rangkah Kidul, Sidoarjo. The timing of health education in accordance with the planned. The students who attended were 40 students. The participants seemed enthusiastic in the process of delivering the material.

Equipment used during the counseling process are laptops, powerpoints, videos, leaflets, LCDs, posters. Using simple language and sentences, students of the Elementary School of Rangkah Kidul, Sidoarjo responded with enthusiasm. The teachers of the Elementary School of Rangkah Kidul, Sidoarjo want to work together in implementing this health promotion activity.

Every question asked by participants can be answered by all team members. $90 \%$ of participants can explained the meaning of clean and healthy life behavior; $90 \%$ of participants can explained the kinds of clean and healthy living behaviors; and $80 \%$ of participants can practiced how to wash hands properly.

\section{CONCLUSION}

Improving knowledge about clean and healthy living behaviors in children of the Elementary School of Rangkah Kidul, Sidoarjo was considered quite successful because $90 \%$ of participants can explained the meaning of clean and healthy life behavior; $90 \%$ of participants can explained the kinds of clean and healthy living behaviors; and $80 \%$ of participants can practiced how to wash hands properly.

\section{REFERENCES}

Annisa, F., Muhebbi, M., Devi, R., Tanzila, C., Windarta, B. E., Aslina, N., ... \& Putri, N. (2019). HEALTHY LIFE AWARENESS IMPROVEMENT THROUGH HANDWASH HEALTH PROMOTION IN THE KEBONSARI ELEMENTARY SCHOOL, CANDI SUB-DISTRICT, SIDOARJO DISTRICT, EAST JAVA PROVINCE. Community Service Journal of Indonesia, 1(1), 4-7.

NN. (2013). SAP Perilaku Hidup Sehat. Retrieved from http://macrofag.blogspot.com/2013/03 /sap-perilaku-hidup-sehat-phs.html.

Sulistyowati, A., Azizah, N., Putri, B. A., Masrikat, E. D., Amalia, L. R., Safira, M., ... \& Muhammad, I. (2019). HEALTHY LIFE AWARENESS IMPROVEMENT THROUGH 
HANDWASH

HEALTH

PROMOTION IN THE

KINDERGARTEN OF SENTUL

VILLAGE, TANGGULANGIN SUB-

DISTRICT,

SIDOARJO

DISTRICT. Community Service

Journal of Indonesia, 1(1), 11-13.

Tanuwidjaja, V. (2018). Satuan Acara

Penyuluhan (SAP): Siswa-siswa

Sekolah Dasar negeri (SDN) 05 dan 08

Pela Mampang, Mampang Prapatan.

Retrieved

from

https://docplayer.info/52991143-Sap-

satuan-acara-penyuluhan-siswa-

siswa-sekolah-dasar-negeri-sdn-05-

dan-08-pela-mampang-mampang-

prapatan.html. 